\title{
Turkish leaders and their foreign policy decision- making style: a comparative and multi-method perspective
}

\section{Ç. Esra Çuhadar, Juliet Kaarbo, Barış Kesgin \& Binnur Özkeçeci-Taner}

To cite this article: Ç. Esra Çuhadar, Juliet Kaarbo, Barıș Kesgin \& Binnur Özkeçeci-Taner (2021) Turkish leaders and their foreign policy decision-making style: a comparative and multi-method perspective, Turkish Studies, 22:1, 1-27, DOI: 10.1080/14683849.2020.1724511

To link to this article: https://doi.org/10.1080/14683849.2020.1724511

\section{Published online: 09 Feb 2020.}

Submit your article to this journal $₫$

LIII Article views: 1486

Q View related articles ¿

View Crossmark data \lceil

Citing articles: 4 View citing articles ¿ð 


\title{
Turkish leaders and their foreign policy decision- making style: a comparative and multi-method perspective
}

\author{
Ç. Esra Çuhadar ${ }^{a}$, Juliet Kaarbo ${ }^{b}$, Barış Kesgin (10 ${ }^{c}$ and Binnur Özkeçeci- \\ Taner (10 ${ }^{\mathrm{d}}$
}

aDepartment of Political Science and Public Administration, Bilkent University, Ankara, Turkey; ${ }^{b}$ Department of Politics and International Relations, University of Edinburgh, Edinburgh, UK; 'Department of Political Science and Policy Studies, Elon University, Elon, NC, USA;

${ }^{d}$ Department of Political Science, Hamline University, St. Paul, MN, USA

\begin{abstract}
Using both quantitative and qualitative research techniques, we investigate the effect of leaders' style and personality on foreign policy. The study examines six Turkish leaders, Süleyman Demirel, Bülent Ecevit, Necmettin Erbakan, Recep Tayyip Erdoğan, Abdullah Gül, and Turgut Özal, and 18 foreign policy cases to answer the following questions: do Turkish leaders differ from each other in terms of their personality traits and styles?; how did their styles affect their foreign policy choices?; and how did they react to various domestic and international constraints they encountered in cases of foreign policy? Our findings suggest that: (a) in terms of their personality traits, Turkish leaders do not collectively fit in one category; (b) there are some stark differences among our six leaders, although some leaders are more similar to each other than others in terms of their personality traits and styles; (c) these differences were observable in the foreign policy decisions they made.
\end{abstract}

ARTICLE HISTORY Received 20 May 2019; Accepted 10 January 2020

KEYWORDS Turkish foreign policy; Turkish leaders; leadership; leadership trait analysis; foreign policy analysis

\section{Introduction}

Former Secretary of State Henry Kissinger mentioned in an interview that ' $[\mathrm{He}]$ tended to think of history as run by impersonal forces, but when you see it in practice, you see the difference personality makes. ${ }^{1}$ As this quote captures, leadership is important and makes a difference. Furthermore, the existing literature persuasively shows that we can systematically evaluate the impact of leadership styles and personal traits on foreign policy decisions. ${ }^{2}$ We also know that presidents (or, heads of states) are not the only leaders 
that affect (foreign) policymaking. In parliamentary systems, for example, the prime minister (the leader of the governing cabinet) plays an important role in the policymaking process. Prime ministers become important because they control 'the selection and dismissal of ministers, cabinet structures' and becomes more proficient in controlling the right to appoint the cabinet. ${ }^{3}$ In addition, prime ministers, who are usually the heads of the major party in parliament have 'solid power over the[ir] parties."

We argue that foreign policymaking involves a dynamic relationship between political leadership as agency and the international, institutional, normative and cultural constraints as structures. 'Structure' is the context in which decision and action takes place; it not only limits but also shapes and propels behavior. 'Agency' is the role of humans and their individual characteristics in the decision-making process. The analysis of foreign policy is just as vulnerable to the 'agency-structure problem,' which, according to Dessler,

emerges from two uncontentious truths about social life: first, that human agency is the only moving force behind actions, events, and outcomes of the social world; and second, that human agency can be realized only in concrete historical circumstances that condition the possibilities for action and influence its course. ${ }^{5}$

To address agent-structure dynamics, and consistent with Giddens' structuration theory, ${ }^{6}$ we contend that foreign policy analysis should provide a detailed examination of leaders' beliefs, personal traits, styles and a comprehensive evaluation of important structural conditions. Giddens argues that although individuals are not entirely free to choose their own actions, they nonetheless are the agency that reproduces social structures. For Giddens, structures-as much as they may put limitations on agents- are created, maintained, and changed through the agents' actions. This study does not assume that it is the leaders that make all the difference in foreign policy. We are against such theoretical reductionism. Similarly, we disagree with the common view in the literature that structural factors dictate what decision makers can do in foreign policy. We find theories that prioritize the systemic factors overly deterministic.

Structural explanations of state behavior are familiar to students of international politics. From the neo-realist focus on anarchy and distribution of power to liberalism's expectations on the constraining factors of economic interdependent structures and international regimes, state behavior is seen as a product of international pressures faced by states and their leaders. ${ }^{7}$ In the Turkish context, numerous examples of scholarship focusing on different structural factors can be found. Guner and Koc, for example, examine the effects of structural factors on Turkish foreign policy in Syria. ${ }^{8}$ Kirisci and Kaptanoglu investigate the effects of economic interdependence on state behavior. ${ }^{9}$ Similarly, Tezcur and Grigorescu scrutinize Turkey's 
activism in its surrounding regions, specifically focusing on the diversification of the county's political and economic interests following the important structural shifts that took place after the end of the Cold War. ${ }^{10}$ System-level constructivism also focuses on the role of (normative) structures to explain state behavior according to logics of appropriateness and constructed expectations of self and other. ${ }^{11}$

Other constructivists, who look inside the state at the domestic-societal level, point to cultural norms and values, operating as structures of constraint on leaders and foreign policy. ${ }^{12}$ Yanik's work scrutinizes the 'exceptionalism' notion and its effect on Turkish foreign policy. ${ }^{13}$ Bilgin critically evaluates another discourse and cultural construct 'strong state surviving in a tough neighbourhood' notion that has shaped Turkish foreign and security policy for many years. ${ }^{14}$ The cultural explanation of democratic peace focuses on societal norms and values that encourage peaceful means of conflict resolution when democratic states are dealing with other democracies that share similar liberal values. ${ }^{15}$ The institutional explanation of the democratic peace stresses the role of institutional structures and the constitutional checks and balances that tie the hands of leaders through accountability to a more peaceful public. ${ }^{16}$ Both rational choice theories of domestic costs and neo-classical realism's conception of the executive, who must bargain with domestic political actors to extract resources in order to respond to international pressures, also see political-domestic structures as limits on security policy. ${ }^{17}$

Other domestic, institutional factors can constrain leaders. Government structures that create multi-party coalitions, for example, put multiple actors, or "veto-players" in control of policymaking. Multiparty governments can bog down decision making and create fragmented policy and excessive compromises; coalition governments may be more vulnerable to junior party influence and inter-party politics. ${ }^{18}$ In addition, decision-making rules, legal provisions as provided by the constitution (i.e. which decisions need to be made or approved by the parliament), different institutional arrangements that lead to formation of different decision-units, the relationship between the executive and the legislature, as well as within party disagreements can create further structural constraints on foreign policy-making. ${ }^{19}$

In short, many approaches to international relations and foreign policy emphasize the constraints imposed on political leaders by various structural forces. Whereas some foreign policy scholars pay attention to the interplay between agency and structure, the literature is mostly silent on the fact that many 'constraints are open to multiple interpretations or can be overcome in the short term (though the longer-term political or personal consequences may be very serious). ${ }^{20}$ Moreover, 'contrary to prevailing structure-based theories, potential constraints in any political environment must be activated by leaders' responsiveness to them before they can influence policy behaviour. ${ }^{21}$ 
We argue that how leaders cope with these domestic and structural constraints are conditioned by their personalities and styles. In other words, we argue that leaders' actions are not determined by structures, but instead leaders interact with structures while they make foreign policy. ${ }^{22}$ We agree with Walker that it is really an empirical question as to whether leaders are aware, and if they are, whether they respond with the calculations of costs and benefits specified by the weights assigned to external focal points in a structural explanation. ${ }^{23} \mathrm{We}$ also contend that the dynamic relationship between agency and structure can be examined 'only by looking at the policymaking processes within states ${ }^{24}$-how do agents interpret, manage, and respond to structural constraints when they make policy decisions? We argue that the question of how structural constraints are shaped and interpreted by leaders and whether or not all agents are equally constrained or empowered by structures is one that requires detailed attention. This study contributes to the study of Turkish foreign policy via its multi-methodological and comparative approach illustrated in various case studies. We also contribute more broadly to Foreign Policy Analysis and International Relations by further exploring the ways in which leaders, as agents, react to domestic and international structures.

\section{Method of evaluation}

We utilize different methods to study the impact of political leaders in foreign policymaking while working under different domestic and international constraints. First, we determined the leadership styles of six Turkish leaders using the Leadership Trait Analysis (LTA). Second, we analyzed 18 foreign policy cases to examine the foreign policymaking of these six leaders under domestic and international constraints, and compared them with each other in order to detect whether or not the Turkish leaders acted in these cases in ways that were suggested by our LTA findings. Our objective was to find out if LTA provided good predictions about how each leader would act when making foreign policy. Conducting in-depth qualitative case studies was important, especially to test LTA (a method applied universally to study leaders around the world) within the specific Turkish context. This is one of the contributions of this paper to the LTA literature as well, because there are not many LTA studies conducted in non-Western contexts and not many using a mixed method approach combining quantification of leadership traits with indepth analysis of the specific foreign policy context.

We studied the leadership styles of six Turkish leaders: Süleyman Demirel, Bülent Ecevit, Necmettin Erbakan, Recep Tayyip Erdoğan, ${ }^{25}$ Abdullah Gül, and Turgut Özal. Over the years, Turkey had to deal with some very similar foreign policy issues and Turkey's leaders have had to make certain decisions about these same issues. For example, Turkey's long-standing 
relations with the European Union is a topic that has confronted all Turkish leaders. Similarly, the Turkey-United States strategic alliance that began after World War II is an important issue all leaders addressed. In addition, crises and war have become the hallmark of the Middle East and they have always created a challenge for Turkish leaders. For example, despite minor differences in the international context, both Özal and Erdoğan had to tackle important decisions regarding the 1991 and 2003 Iraq wars. ${ }^{26}$

We chose these leaders also because individually, and as a set, these leaders offer a natural quasi-experimental design for examining how different leaders may interpret similar domestic and international constraints. For example, Özal, Gül, Demirel and Erdoğan held positions as both presidents and prime ministers. Additionally, Özal, Erdoğan and Gül operated in oneparty governments whereas Demirel, Erbakan and Ecevit were prime minister in coalition government settings. One-party vs. coalition settings certainly provide different types of limitations on leaders. We should note that until very recently, prime ministers were especially important in Turkish politics as the constitution gave them more legislative and executive powers than it did to the President. The Presidency was typically viewed as a symbolic position and many presidents had interpreted their role as one that was 'above politics.' However, some Turkish presidents chose to get directly involved in policymaking. For example, Özal was very active in foreign policymaking, Demirel showed interest in certain foreign policy issues; in contrast, Ahmet Necdet Sezer (not profiled here) did not play any major role in foreign affairs. Sezer did not even travel abroad much to meet with his counterparts. Although it is certainly the case that the international context changed over the course of these leaders' time in office, our cases demonstrate that these structural contexts were not determinant of Turkish foreign policy choices. There was often disagreement about the nature of that international context and how to respond to it. Our central argument is that leaders and their personality traits played an important role in how Turkey responded to international structures, regardless of the nature of those structures.

\section{Leadership trait analysis (LTA)}

To determine the personalities and styles of the six Turkish leaders mentioned above, we utilized LTA. Margaret Hermann developed LTA, based on many years of research on personality traits of leaders especially in the foreign policy domain. ${ }^{27}$ This framework renders different leadership styles based on seven personality traits: belief in ability to control events (BACE), conceptual complexity (CC), need for power (PWR), distrust towards others (DIS), in-group bias (IGB), self-confidence (SC), and task orientation (TASK). Table 1 presents brief information about each trait. LTA profiles are reliable ${ }^{28}$ and scholars have used it to analyze personalities and leadership styles of American, 
Table 1. Personality characteristics in LTA.

\begin{tabular}{|c|c|c|}
\hline Trait & Description & Coding \\
\hline $\begin{array}{l}\text { Belief in ability to } \\
\text { control events } \\
\text { (BACE) }\end{array}$ & $\begin{array}{l}\text { Perception of own degree of control } \\
\text { over political world }\end{array}$ & $\begin{array}{l}\text { Percentage of verbs used that reflect action } \\
\text { or planning for action of the leader or } \\
\text { relevant group. }\end{array}$ \\
\hline $\begin{array}{l}\text { Need for power } \\
\text { (PWR) }\end{array}$ & $\begin{array}{l}\text { Interest in developing, preserving, } \\
\text { or reinstituting own power }\end{array}$ & $\begin{array}{l}\text { Percentage of verbs that reflect actions of } \\
\text { attack, advise, influence behavior of } \\
\text { others, concern with reputation }\end{array}$ \\
\hline $\begin{array}{l}\text { Conceptual } \\
\text { complexity (CC) }\end{array}$ & $\begin{array}{l}\text { Ability to distinguish complexities } \\
\text { of political life }\end{array}$ & $\begin{array}{l}\text { Percentage of words related to high } \\
\text { complexity (e.g. 'approximately', } \\
\text { 'possibility', 'trend') vs. low complexity } \\
\text { (e.g. 'absolutely', 'certainly', 'irreversible'). }\end{array}$ \\
\hline Self-confidence (SC) & $\begin{array}{l}\text { Notion of self-importance, and of } \\
\text { his/her capacity to take on the } \\
\text { political environment. }\end{array}$ & $\begin{array}{l}\text { Percentage of personal pronouns used (e.g. } \\
\text { 'my', 'myself', 'I', 'me', 'mine') which show } \\
\text { speaker perceives self as instigator of an } \\
\text { activity, an authority figure, or a recipient } \\
\text { of a positive reward. }\end{array}$ \\
\hline In-group bias (IGB) & $\begin{array}{l}\text { Belief that own group constitutes } \\
\text { the center of political world }\end{array}$ & $\begin{array}{l}\text { Percentage of references to group that are } \\
\text { favorable (e.g. 'successful', 'great'), show } \\
\text { strength (e.g. 'powerful', 'capable') or a } \\
\text { need to maintain group identity (e.g. } \\
\text { 'decide our own policies', 'defend our } \\
\text { borders'). }\end{array}$ \\
\hline $\begin{array}{l}\text { Distrust of others } \\
\text { (DIS) }\end{array}$ & $\begin{array}{l}\text { Suspicions, skepticism, worry of } \\
\text { others than own group }\end{array}$ & $\begin{array}{l}\text { Percentage of nouns that indicated } \\
\text { misgivings or suspicions that others } \\
\text { intend harm toward speaker or speaker's } \\
\text { group. }\end{array}$ \\
\hline Task focus (TASK) & $\begin{array}{l}\text { Concentration on problem solving } \\
\text { vs. building relationships }\end{array}$ & $\begin{array}{l}\text { Percentage of words related to } \\
\text { instrumental activities (e.g. } \\
\text { 'accomplishment', 'plan', 'proposal) vs. } \\
\text { concern for others' feelings and desires } \\
\text { (e.g. 'collaboration', 'amnesty', } \\
\text { 'appreciation'). }\end{array}$ \\
\hline
\end{tabular}

Source: Adapted from Dyson, "Personality and Foreign Policy".

British, African, European, Iranian, and Israeli leaders, members of the Soviet Politburo, as well as the heads of international organizations. ${ }^{29}$

For LTA coding, it is assumed that the more frequently leaders use certain words and phrases when they speak, the more apparent and salient such content is to them, and the more it reflects underlying personality traits. ${ }^{30}$ LTA coding is quantitative and employs frequency counts taking the word or phrase as the unit of analysis. Early LTA research used hand-coding techniques; in the early 2000s, computer programs have been developed to code leaders' verbal acts to produce more reliable assessments at greater speeds and volume. ${ }^{31}$ One such computer program is ProfilerPlus. ${ }^{32}$ The program determines the percentage of particular words and phrases used by the leaders based on the length of the text. ${ }^{33}$

The advantage of using the LTA framework for investigating agent-structure relations is that LTA provides specific expectations regarding which characteristics of agents matter and how in leaders' orientations toward structures. In other words, leaders with different traits are expected to relate to their context, institutional setting, costs and benefits of various policy options, and 
other agents in theoretically meaningful and predictable ways. Indeed, decades of LTA-based research have demonstrated that leaders vary in how they respond to their environments. Some confront structural barriers and pressures; others defer to or work within them. For leaders who challenge constraints, for example, their own beliefs and style will be reflected in policymaking processes and foreign policy choices. ${ }^{34}$ According to Hermann, a leader's belief in ability to control events and influence their environment, as well as their need for higher power provides enough clues to tell us whether that leader will accept or challenge structurally imposed limitations. ${ }^{35}$

In addition to their belief in ability to control events, to influence the environment, and their need for power, leaders also differ from each other in terms of their conceptual complexity and self-confidence. They also show variation in terms of their in-group vs. out-group bias and their relationship (task vs. personal) orientation. For example, a combined effect of how conceptually complex and self-confident a leader is will have an impact on how this person receives information and from whom. When we combine all of these traits, we can then discover the leadership style of each individual.

Tables 2-4(this should be Tables 2-4) specify how the traits relate to the questions asked above concerning leadership style and how each trait is related to one another regarding an important aspect of leadership style. For example, Table 2 illustrates that a combined effect of need for power (PWR) and belief in ability to control events (BACE) determines whether a leader is likely to challenge or respect constraints. Similarly, the relationship between conceptual complexity (CC) and self-confidence (SC) as seen in Table 3 provides clues about how open or closed a leader is to outside information. It should be noted that when the scores on CC and SC are fairly close, 'leaders' behavior will depend on whether the scores the scores are high or low when compared to other leaders. ${ }^{36}$ If both are high, leaders will be open to information; if both are low, they will be closed to it. By using the LTA, we can also determine if a leader is problem-oriented or relationship-oriented

Table 2. Leaders' orientation to constraints.

\begin{tabular}{|c|c|c|}
\hline \multirow{2}{*}{$\begin{array}{l}\text { Need for } \\
\text { Power }\end{array}$} & \multicolumn{2}{|c|}{ Belief in Ability to Control Events } \\
\hline & Low & High \\
\hline Low & $\begin{array}{l}\text { Respects constraints; work within such } \\
\text { parameters toward goals; compromise and } \\
\text { consensus building important. }\end{array}$ & $\begin{array}{l}\text { Challenges constraints; but less successful } \\
\text { in doing so because too direct and open in } \\
\text { use of power; less able to read how to } \\
\text { manipulate people and setting behind the } \\
\text { scenes to have desired influence. }\end{array}$ \\
\hline High & $\begin{array}{l}\text { Challenges constraints; but more } \\
\text { comfortable doing so in an indirect fashion- } \\
\text { behind the scenes; good at being 'power } \\
\text { behind the throne' where they can pull } \\
\text { strings but are less accountable for result. }\end{array}$ & $\begin{array}{l}\text { Challenges constraints; are skillful in both } \\
\text { direct and indirect influence; know what } \\
\text { they want and take charge to see that it } \\
\text { happens. }\end{array}$ \\
\hline
\end{tabular}

Source: Hermann, "Assessing Leadership Style," 188. 
Table 3. Openness to information.

\begin{tabular}{ll}
\hline Complexity and Confidence Traits & Open vs. Closed to Information \\
\hline Conceptual Complexity $>$ Self-confidence & Open \\
Conceptual Complexity $<$ Self-confidence & Closed \\
Both high $>$ average & Open \\
Both low $<$ average & Closed \\
\hline Sour
\end{tabular}

Source: Adapted from Hermann, "Assessing Leadership Style," 194.

Table 4. Motivation toward world.

\begin{tabular}{|c|c|c|}
\hline \multirow{2}{*}{$\begin{array}{l}\text { In-group } \\
\text { bias }\end{array}$} & \multicolumn{2}{|c|}{ Distrust of Others } \\
\hline & Low & High \\
\hline Low & $\begin{array}{l}\text { World is not a threatening place; conflicts are } \\
\text { perceived as context-specific and are } \\
\text { reacted to on a case-by-case basis; leaders } \\
\text { recognize that their country, like many } \\
\text { others, has to deal with certain constraints } \\
\text { that limit what one can do and call for } \\
\text { flexibility of response; moreover, there are } \\
\text { certain international arenas where } \\
\text { cooperation with others is both possible } \\
\text { and feasible. (Focus is on taking advantage } \\
\text { of opportunities and relationships) }\end{array}$ & $\begin{array}{l}\text { World is perceived as conflict-prone, but } \\
\text { because other countries are viewed as } \\
\text { having constraints on what they can do, } \\
\text { some flexibility in response is possible; } \\
\text { leaders, however, must vigilantly monitor } \\
\text { developments in the international arena } \\
\text { and prudently prepare to contain an } \\
\text { adversary's actions while still pursuing their } \\
\text { countries' interests. (Focus is on taking } \\
\text { advantage of opportunities and building } \\
\text { relationships while remaining vigilant) }\end{array}$ \\
\hline High & $\begin{array}{l}\text { While the international system is essentially a } \\
\text { zero-sum game, leaders view that it is } \\
\text { bounded by a specified set of international } \\
\text { norms; even so, adversaries are perceived } \\
\text { as inherently threatening and } \\
\text { confrontation is viewed to be ongoing as } \\
\text { leaders work to limit the threat and } \\
\text { enhance their countries' capabilities and } \\
\text { relative status. (Focus is on dealing with } \\
\text { threats and solving problems even though } \\
\text { some situations may appear to offer } \\
\text { opportunities) }\end{array}$ & $\begin{array}{l}\text { International politics is centered around a set } \\
\text { of adversaries that are viewed as 'evil' and } \\
\text { intent on spreading their ideology or } \\
\text { extending their power at the expense of } \\
\text { others; leaders perceive that they have a } \\
\text { moral imperative to confront these } \\
\text { adversaries; as a result, they are likely to } \\
\text { take risks and to engage in highly } \\
\text { aggressive and assertive behavior. (Focus is } \\
\text { on eliminating potential threats and } \\
\text { problems) }\end{array}$ \\
\hline
\end{tabular}

Source: Hermann, "Assessing Leadership Style," 200.

using the LTA approach. Finally, as shown in Table 4, a combined effect of ingroup bias (IGB) and distrust towards others (DIS) reveals of a leader will focus on taking advantage of opportunities and relationships or dealing with threats.

Although LTA and other at-a-distance assessments are now, with machine-coding, reliable, they continue to face a central question of validity: do the words of leaders truly reflect their personal beliefs and personality characteristics? This question often revolves around concerns about authorship, audience effects and deception, temporal stability, and language differences. However, in a recent review of the literature, Preston concludes that

LTA is the most rigorous and well-tested of current profiling techniques due to its decades-long track record of research, meticulous empirical work validating its links to actual behavior, and the sophisticated nature of its automation into 
the Profiler-Plus expert system that effectively eliminates intercoder reliability issues. $^{37}$

For our study, we address authorship, audience effects and similar issues by using only interviews and other spontaneous material -and, not prepared speeches, aggregating the data across audience, and assuming that leaders' characteristics can be meaningfully assessed in English (if the text was originally spoken in English) or in English translations.

We gathered these first-hand sources from newspaper archives, and electronic databases. In addition, we also used websites of political parties and the Office of the President and the Office of Prime Minister. The numbers of verbal acts (interviews or other spontaneous material) we collected for each of our six leaders are as follows: Süleyman Demirel: 145, Bülent Ecevit: 100, Necmettin Erbakan: 83, Recep Tayyip Erdoğan: 126, Abdullah Gül: 75, and Turgut Özal: 73. The total number of data points (words) in these materials is over 500,000 - well above the total number required to do a reliable and meaningful leadership trait analysis. Furthermore, all of the materials are selected from among those containing foreign policy related topics.

Once we collected the materials, we classified and coded the data based on the criteria provided by ProfilerPlus. Then, we calculated the scores for each trait described in Table 1. Then, we compared the scores obtained for each leader on each trait (discussed below) with different norming groups to determine whether that leader stands below, at, or above the average. Standard deviations in the norming group is calculated to make this comparison. In our analysis, we compare the scores of Turkish leaders to two norming groups. The first is comprised of 284 world leaders, in which there are very few Turkish leaders (and thus alone do not significantly impact the average or standard deviation). We also compare our six leaders to a Turkish-only norming group. We can thus see if results differ across these two norming groups. By comparing their standing among the world leaders and the Turkish leaders, we were able to make more accurate predictions about their personality traits. According to the last two columns in Table 5, the mean scores for all traits do not change much between the world norming group and the Turkish norming group except for self-confidence trait. However, there is considerable difference between the two norming groups in terms of standard deviations. This is expected as the world leaders norming group is a highly heterogeneous group of leaders from around the world, whereas the second one is a culture-specific group, hence much less diverse. Finally, we determined the styles of our six leaders. While our primary purpose in this project is to use LTA -a well-known theoretical framework and methodological tool- we also contribute to its development by examining several leaders from within the same political system, by extending LTA research beyond the United States and Western European context, and by providing profiles of these leaders that can be used in further studies. 
Table 5. Comparing Turkish leaders with world leaders.

\begin{tabular}{|c|c|c|c|c|c|c|c|c|}
\hline $\begin{array}{l}\text { Leaders } \\
\text { Traits }\end{array}$ & Demirel & Ecevit & Erbakan & Erdoğan & Gül & Özal & $\begin{array}{l}284 \text { World Leaders } \\
\text { (Hermann 2012) }\end{array}$ & $\begin{array}{c}\text { Turkish Leaders } \\
\text { as a Group }\end{array}$ \\
\hline BACE & .360 & .302 & .340 & .384 & .306 & .371 & $\begin{array}{c}\text { Mean }=.35 \\
(\mathrm{sd} .=.05)\end{array}$ & $\begin{array}{c}\text { Mean }=.344 \\
(\text { sd. }=.034)\end{array}$ \\
\hline CC & .586 & .617 & .529 & .598 & .576 & .651 & $\begin{array}{c}\text { Mean }=.59 \\
(\mathrm{sd} .=.06)\end{array}$ & $\begin{array}{l}\text { Mean }=593 \\
(\text { sd. }=.041)\end{array}$ \\
\hline DIS & .124 & .114 & .144 & .116 & .130 & .134 & $\begin{array}{l}\text { Mean }=.13 \\
(\mathrm{sd} .=.06)\end{array}$ & $\begin{array}{l}\text { Mean }=.127 \\
(\mathrm{sd} .=.011)\end{array}$ \\
\hline IGB & .131 & .143 & .135 & .090 & .127 & .116 & $\begin{array}{l}\text { Mean }=.15 \\
(\mathrm{sd}=.05)\end{array}$ & $\begin{array}{l}\text { Mean }=.124 \\
(\text { sd. }=.019)\end{array}$ \\
\hline PWR & .277 & .260 & .278 & .243 & .233 & .229 & $\begin{array}{l}\text { Mean }=.26 \\
(\mathrm{sd} .=.05)\end{array}$ & $\begin{array}{l}\text { Mean }=.253 \\
(\mathrm{sd} .=.022)\end{array}$ \\
\hline SC & .403 & .505 & .317 & .356 & .484 & .453 & $\begin{array}{l}\text { Mean }=.36 \\
(\mathrm{sd} .=.10)\end{array}$ & $\begin{array}{l}\text { Mean }=.420 \\
(s d .=.074)\end{array}$ \\
\hline TASK & .601 & .664 & .537 & .649 & .687 & .656 & $\begin{array}{c}\text { Mean }=.63 \\
(\mathrm{sd} .=.07)\end{array}$ & $\begin{array}{l}\text { Mean }=.632 \\
(\mathrm{sd} .=.054)\end{array}$ \\
\hline
\end{tabular}

\section{Case studies}

We examined the validity of our LTA results and categorization of the six leaders chosen for this study by an in-depth examination of 18 foreign policy cases (see Table 8). This qualitative part of the study was based on two sources: available literature (both scholarly and not-scholarly) regarding the particular foreign policy event, and 20 semi-structured interviews with former government officials, political party members and advisors of leaders in 2013. Among our selected leaders, Süleyman Demirel was the only one we were able to interview personally.

We selected three foreign policy cases for each of our six political leaders. Our cases focused on Turkey's relations with the European Union, TurkishUS strategic alliance, and Turkey's foreign policy toward the Middle East. We decided to focus on these three topics in order to control variation in international or systemic constraints as much as possible. Furthermore, the foreign policy cases were selected based on their importance at the time and because each leader under study had to respond to or take an initiative regarding them. The importance of these cases was determined by examining (1) newspaper coverage, (2) academic writings on Turkish foreign policy, and (3) discussions with Turkey experts.

\section{Results and discussion}

\section{Comparison of LTA scores of Turkish leaders with those of the norming group}

When we compare the scores of our six leaders (Table 5) with the scores of the norming group of 284 world leaders, we see that there is no one certain personality trait that differentiates the Turkish leaders from others, although our 
group of Turkish leaders as a whole has a considerably higher score in SC in comparison to the score of the world leaders on this trait. Whereas the mean score for the six Turkish leaders is .420, the mean score for our norming group is .36 .

When we compare individual Turkish leaders with the norming group, we see that some Turkish leaders have higher scores (not always statistically significant) than the average scores of the norming group. For example, Özal and Ecevit have very high complexity scores compared to the average score of the world leaders. Similarly, four Turkish leaders -Demirel, Ecevit, Gül, Özalhave considerably higher SC scores in comparison to the average score of the norming group. It is also interesting to note that the IGB scores of all six Turkish leaders are lower than the average score.

\section{Comparison of LTA scores of Turkish leaders amongst themselves}

In terms of their personality traits, it is difficult categorize all Turkish leaders in one category. As Table 6 shows, there are some stark differences among the six leaders, although some leaders are more similar to each other than others in terms of their personality traits and styles. For example, the following pairs of leaders show more similarities with one another: Erdoğan and Özal; Demirel and Erbakan; Ecevit and Gül.

\section{Turkish leaders' orientation toward constraints, openness to information, and motivation toward world}

Both Erdoğan and Özal have high BACE scores. Similarly, both also have low scores in IGB and are problem-oriented. Demirel and Erbakan are similar in that they are relationship-oriented and that they have high scores in IGB and PWR. Likewise, these leaders have low scores for SC and CC. Ecevit and Gül show similarities in terms of their scores regarding the BACE (low), IGB (high), SC (high) and problem-orientation (high). Finally, scores of Gül and Özal illustrate that they both have distrust towards others (high); they are problem-oriented (high) and their scores for PWR is low. On the other hand, those leaders who have high SC scores -Ecevit, Gül, Özal- are also task-oriented. Erbakan, Gül and Ecevit, who have low scores on BACE are also the ones that scored high on PWR and IGB. As it will be remembered, a leader's response to constraints is determined based on their scores on two traits: need for power and belief in one's ability to control events.

With regard to orientation toward constraints, we have five leaders who challenge constraints and one leader that respects constraints. Among the five constraint challenges, Özal and Erdoğan (with low PWR and high BACE scores) are likely to use their status directly and act in accordance with the belief that they will achieve their goals. On the other hand, our 
Table 6. Comparing Turkish leaders within the group*.

\begin{tabular}{|c|c|c|c|c|c|c|c|c|c|c|c|}
\hline \multicolumn{4}{|c|}{ BACE } & \multicolumn{2}{|c|}{ PWR } & \multicolumn{4}{|c|}{$\mathrm{CC}$} & \multicolumn{2}{|c|}{ SC } \\
\hline Erdoğan & .384 & & Erbakan & .278 & & Özal & .651 & & Ecevit & .505 & \\
\hline Özal & .371 & hi-.378 & Demirel & .277 & $h i-.275$ & Ecevit & .617 & hi-.634 & Gül & .484 & hi-.494 \\
\hline Demirel & .360 & & Ecevit & .260 & & Erdoğan & .598 & & Özal & .453 & \\
\hline average & .344 & $s d-.034$ & average & .253 & $s d-.022$ & average & .593 & $s d-.041$ & average & .420 & $s d-.074$ \\
\hline Erbakan & .340 & & Erdoğan & .243 & & Demirel & .586 & & Demirel & .403 & \\
\hline Gül & .306 & $10-.310$ & Gül & .233 & $10-.332$ & Gül & .576 & $10-.552$ & Erdoğan & .356 & $10-.346$ \\
\hline \multirow[t]{2}{*}{ Ecevit } & .302 & & Özal & .229 & & Erbakan & .529 & & Erbakan & .317 & \\
\hline & \multicolumn{2}{|c|}{ DIS } & & \multicolumn{2}{|c|}{ IGB } & & \multicolumn{2}{|c|}{ TASK } & & & \\
\hline Erbakan & .144 & & Ecevit & .143 & & Gül & .687 & & & & \\
\hline Özal & .134 & $h i-.138$ & Erbakan & .135 & hi-. 143 & Ecevit & .664 & hi-.687 & & & \\
\hline Gül & .130 & & Demirel & .131 & & Özal & .656 & & & & \\
\hline average & .127 & $s d-.011$ & average & .127 & $s d-.019$ & average & .649 & $s d-.054$ & & & \\
\hline Demirel & .124 & & Gül & .124 & & Erdoğan & .632 & & & & \\
\hline Erdoğan & .116 & $10-.116$ & Özal & .116 & $10-.105$ & Demirel & .601 & $10-.578$ & & & \\
\hline Ecevit & .114 & & Erdoğan & .090 & & Erbakan & .537 & & & & \\
\hline
\end{tabular}

${ }^{*}$ sd $=$ standard deviation, lo $<1<\mathrm{hi}$; if within one standard deviation, then average. 
two other leaders - Erbakan and Ecevit - who have high PWR and low BACE scores will use 'behind the scenes' strategies in their attempt to challenge constraints. Finally, Demirel who has high PWR and BACE scores will challenge constraints in the most skillful ways, utilizing different tactics and strategies. Gül, the only constraints respecter in our group of leaders, will choose to work within such parameters toward goals.

Based on their scores on SC and CC, we can also conclude that whereas Erbakan is definitely closed to information and both Özal and Ecevit are open to it, Erdoğan, Demirel, and Gül may or may not be open to information. According to the LTA, this contingency is resolved by context and the nature of issue are important to determine what kinds of issues and which circumstances will lead the latter three leaders to be open to outside information.

Finally, regarding Turkish leaders' motivation toward the external world, we see some similarities and differences. A leader's orientation toward world can be deduced from their scores on IGB and DIS. As shown in Table 6, among our leaders, Erbakan and Gül have high scores in both IGB and DIS, while Erdoğan has low scores on both traits. On the other hand, Özal scored low on IGB and high on DIS while Demirel's and Ecevit's scores are low on DIS and high on IGB.

\section{Styles of Turkish leaders}

After we combine all of the scores on the seven traits and show how each of them are related to one another, it is now time to determine the leadership styles of our six leaders. Table 7 summarizes our findings.

\section{Styles of Turkish leaders in case studies}

Our analysis of the 18 foreign policy cases leads us to claim that LTA provides reliable and meaningful information about the connection between leaders' styles and the foreign policy choices they make in foreign policy. That LTA accounts for the structural limitations imposed on leaders is crucial in foreign policy analysis. Our case analyses confirmed some important LTAbased predictions not only about the relationship between domestic and international constraints and how leaders challenge or defer to them but also about how leadership styles affect the foreign policy decision making process. For example, both Özal and Erdoğan acted in ways that were consistent with their very high scores on belief in ability to control events and task-orientation. Similarly, it was clear that both Demirel and Erbakan who had high in-group bias and high need for power. Finally, Gül and Ecevit, our two leaders with lower scores on ability to control events, along with high selfconfidence and task-orientation acted as LTA results predicted. As Table 8 
Table 7. Styles of Turkish leaders.

\begin{tabular}{|c|c|c|c|}
\hline \multirow{2}{*}{$\begin{array}{l}\text { Leaders' } \\
\text { orientation } \\
\text { toward } \\
\text { constraints }\end{array}$} & \multirow{2}{*}{$\begin{array}{l}\text { Openness } \\
\text { toward } \\
\text { information }\end{array}$} & \multicolumn{2}{|c|}{ Motivation } \\
\hline & & Problem/task & Relationship \\
\hline $\begin{array}{l}\text { Constraints } \\
\text { challenger }\end{array}$ & Closed & $\begin{array}{l}\text { Recep Tayyip Erdoğan* } \\
\text { Expansionistic } \\
\text { Focus of attention is on } \\
\text { expanding leader's, } \\
\text { government's, and state's span } \\
\text { of control. }\end{array}$ & $\begin{array}{l}\text { Necmettin Erbakan } \\
\text { Süleyman Demirel* } \\
\text { Evangelistic } \\
\text { Focus of attention is on } \\
\text { persuading others to join in } \\
\text { one's mission, in mobilizing } \\
\text { others around one's message. }\end{array}$ \\
\hline $\begin{array}{l}\text { Constraints } \\
\text { challenger }\end{array}$ & Open & $\begin{array}{l}\text { Turgut Özal } \\
\text { Bülent Ecevit } \\
\text { Recep Tayyip Erdoğan* } \\
\text { Actively-independent } \\
\text { Focus of attention is on } \\
\text { maintaining one's own and the } \\
\text { government's maneuverability } \\
\text { and independence in a world } \\
\text { that is perceived to continually } \\
\text { try to limit both. }\end{array}$ & $\begin{array}{l}\text { Süleyman Demirel* } \\
\text { Directive } \\
\text { Focus of attention is on } \\
\text { maintaining one's own and } \\
\text { the government's status and } \\
\text { acceptance by others by } \\
\text { engaging in actions on the } \\
\text { world stage that enhance the } \\
\text { state's reputation. }\end{array}$ \\
\hline $\begin{array}{l}\text { Constraints } \\
\text { respecter }\end{array}$ & Closed & $\begin{array}{l}\text { Abdullah Gül* } \\
\text { Incremental } \\
\text { Focus of attention is on } \\
\text { improving state's economy } \\
\text { and/or security in incremental } \\
\text { steps while avoiding the } \\
\text { obstacles that will inevitably } \\
\text { arise along the way. }\end{array}$ & $\begin{array}{l}\text { Influential } \\
\text { Focus of attention is on } \\
\text { building cooperative } \\
\text { relationships with other } \\
\text { governments and states in } \\
\text { order to play a leadership } \\
\text { role; by working with others, } \\
\text { one can gain more than is } \\
\text { possible on one's own. }\end{array}$ \\
\hline $\begin{array}{l}\text { Constraints } \\
\text { respecter }\end{array}$ & Open & $\begin{array}{l}\text { Abdullah Gül* } \\
\text { Opportunistic } \\
\text { Focus of attention is on } \\
\text { assessing what is possible in } \\
\text { the current situation and } \\
\text { context given what one wants } \\
\text { to achieve and considering } \\
\text { what important constituencies } \\
\text { will allow. }\end{array}$ & $\begin{array}{l}\text { Collegial } \\
\text { Focus of attention is on } \\
\text { reconciling differences and } \\
\text { building consensus - on } \\
\text { gaining prestige and status } \\
\text { through empowering others } \\
\text { and sharing accountability. }\end{array}$ \\
\hline
\end{tabular}

*These leaders' categorization is contingent on whether or not they are open to information.

illustrates, there is a very close match between the styles of the leaders as determined by the LTA and how they behaved in foreign policymaking in the 18 cases we examined. We also have available summary points from our cases analyses. ${ }^{38}$

For example, it was easy to see Demirel's directive leadership style in all three cases. In the Baku-Ceyhan-Tiflis pipeline case he initiated many of the face-to-face presidential meetings/summits and participated in the decision-making process. Similarly, Demirel's meeting with Egyptian President Mubarak was crucial to the outcome of the Turkish-Syrian crisis. At least two of the case studies showed that Demirel might at times be less than willing to compromise to work out a deal with others. Most tellingly, Demirel, who was Prime Minister at the time and President Özal differed 
Table 8. Leadership styles and foreign policy cases.

\begin{tabular}{|c|c|c|c|c|c|c|}
\hline $\begin{array}{l}\text { Leaders } \\
\text { Case }\end{array}$ & Özal & Demirel & Erbakan & Ecevit & Gül & Erdoğan \\
\hline $\begin{array}{l}\text { 1. US- } \\
\text { related }\end{array}$ & $\begin{array}{l}1991 \text { Iraq War } \\
\text { Actively-Independent }\end{array}$ & $\begin{array}{l}\text { Bakü-Ceyhan- } \\
\text { Tiflis Pipeline } \\
\text { Directive }\end{array}$ & $\begin{array}{l}\text { Operation Northern Watch } \\
\text { (Could not challenge constraints } \\
\text { directly, but indirect challenge is } \\
\text { still there) }\end{array}$ & $\begin{array}{l}\text { Armenian Genocide } \\
\text { Decision at the US } \\
\text { Senate } \\
\text { Actively-Independent }\end{array}$ & $\begin{array}{l}2003 \text { Iraq War (1 } \\
\text { March Decision) } \\
\text { Opportunistic }\end{array}$ & $\begin{array}{l}2003 \text { Iraq War (20 March } \\
\text { and } 7 \text { October Decisions) } \\
\text { Expansionistic }\end{array}$ \\
\hline $\begin{array}{l}\text { 2. EU- } \\
\text { related }\end{array}$ & $\begin{array}{l}\text { Rapprochement on } \\
\text { European Security } \\
\text { Framework } \\
\text { Actively-Independent }\end{array}$ & $\begin{array}{l}\text { Bosnian War } \\
\text { Directive }\end{array}$ & $\begin{array}{l}\text { Dublin Summit Decision } \\
\text { (December 1996) } \\
\text { Evangelistic }\end{array}$ & $\begin{array}{l}\text { Helsinki Summit } \\
\text { Decisions (December } \\
\text { 1999) } \\
\text { Actively-Independent }\end{array}$ & $\begin{array}{l}\text { Prag Energy Summit } \\
\text { Incremental }\end{array}$ & $\begin{array}{l}\text { Annan Plan and Cyprus } \\
\text { Negotiations } \\
\text { Expansionistic }\end{array}$ \\
\hline $\begin{array}{l}\text { 3. Middle } \\
\text { East- } \\
\text { related }\end{array}$ & $\begin{array}{l}\text { Water Pipeline Project } \\
\text { Actively-Independent }\end{array}$ & $\begin{array}{l}\text { Syrian Crisis } \\
\text { (1998) } \\
\text { Directive }\end{array}$ & $\begin{array}{l}\text { D-8 Project } \\
\text { Evangelistic }\end{array}$ & $\begin{array}{l}\text { Rapproche-ment with } \\
\text { Iraq } \\
\text { Actively-Independent }\end{array}$ & $\begin{array}{l}\text { Mediation Efforts } \\
\text { re: Iranian } \\
\text { nuclearization } \\
\text { Incremental }\end{array}$ & $\begin{array}{l}\text { The Flotilla Incident (Mavi } \\
\text { Marmara) } \\
\text { Expansionistic }\end{array}$ \\
\hline
\end{tabular}


from each other in Turkey should respond to Armenia during the NagornoKarabakh conflict and Demirel did not hesitate to suggest that those who were suggesting Turkey taking more aggressive policies toward Armenia did not really know where Turkey's best interests lay. Demirel also acted in the three cases under analysis in ways that showed his comfort with uncertainty and flexibility in his reactions to ideas. He would seek a variety of perspectives and would be highly attuned to contextual information. He took time in making decisions and involved a large array of actors in the decisionmaking process. Finally, Demirel also acted in ways that supported the LTA results that he was ready to work with others or the international community as a whole. He used his powers skillfully in both direct and indirect ways and he most likely knew what he wanted and took charge to see it happens. In short, in all three cases, Demirel acted consistent with the conclusion: 'directive leader'. Demirel challenged the constraints such as pressure from the President, from the members of his (former) party or the governing coalition, and from the public in all three cases, rather skillfully and not in threatening ways to others. He tried to persuade and showed that what was needed was to maintain and/or further his/Turkey's interests and reputation in general.

Actions of both Ecevit and Özal in the cases we examined during their tenure illustrated that they did not shy away from making daring or unexpected foreign policy decisions, confirming that both of them belonged to the category of actively-independent leaders. The cases regarding the US Senate's decision about the Armenian Genocide and Turkey's rapprochement with Iraq showed that Ecevit did not hesitate to go against the traditional foreign policy of Turkey towards the United States. As Prime Minister, his reaction to the European Union's 1999 decision showed that he could favor an aggressive foreign policy if he thought that was in Turkey's best interests and if he had supporters. Ecevit was confident not only in his grasp of foreign policy-related matters but also how he managed coalition politics. In addition, following the EU's Helsinki Decisions, he did not hesitate to 'threaten' the Union by suggesting that Turkey could freeze all relations with the Union (note that he was supported by his coalition partners). Similarly, Özal was both task- and relationship-focused. He knew what he wanted to accomplish and thought deeply about how to get to it. When his views clashed with other powerful actors in Turkish politics such as the Military as seen in the 1991 Iraqi War, he did not hesitate to claim that he had a lot more information about the matter and that the Constitution gave him the right to decide on matters relating to national security.

Erbakan showed remarkable consistency and self-confidence in his actions and pursued better relations with the Muslim world despite important domestic constraints. His actions to circumvent the Ministry of Foreign Affairs also points to his (demand for) 'independence in action.' All three cases we examined illustrated that Erbakan did not feel comfortable delegating 
authority, although he surrounded himself with trusted friends and colleagues, who had meetings with Erbakan behind closed doors. His determination to maintain his group and loyalty of his constituencies illustrated his willingness to challenge constraints during his tenure as Prime Minister. Overall, his general foreign policy orientation was a direct challenge to the long-held, traditional foreign policy of Turkey. He certainly showed the signs of an 'evangelistic leader.'

Finally, both Erdoğan and Gül demonstrated behavior that were in line with expansionistic and incremental or opportunistic leadership styles, respectively. In the cases of 2003 Iraq War and the Flotilla Incident, we saw Erdogan's high belief in the ability to control events and active involvement, taking direct action without any hesitation to provoke Israel (or the United States). The 2003 Iraq War case demonstrated that he wanted to control the outcome by actually making his party to vote en bloc on the bill. Erdoğan periodically used direct threats that sometimes resulted in more commitment to a foreign policy issue. In all of the three cases examined, there were many instances that illustrated that he saw the issues in blackand-white, without really showing any interest in looking into the gray areas. Our cases also revealed that Erdoğan was very intent to justify why certain actions needed to be taken or some hard decisions had to be made including the one the Turkish government made following the Annan Plan on Cyprus. The Flotilla Incident illustrated that he usually blamed others when things did not go as planned. He showed commitment to his group and asked for complete loyalty in return.

All three cases we examined demonstrated that Gül respected constraints and used his skills and status to persuade rather than to force others to follow his ideas or policy choices. Even in a situation, where many, considering the constraints, argued that he had taken a huge leap of faith by becoming a mediator in Iranian-Western relations, his respect for challenge was clear. Gül chose to work within established parameters and called for compromise or consensus. In this sense, in line with our LTA findings, Gül acted as an opportunistic leader in the case of the 2003 Iraq War or an incremental leader in the cases of the Prague Energy Summit and the Iranian nuclearization. Most tellingly, in both of these cases, Gül was focused on problems but his focus on relationship was visible in the Iraq War decision.

\section{Conclusions and future research directions}

Turkey presents an excellent laboratory for the study of the interaction of leadership styles and different types of structural constraints. Our findings suggest that whereas there is no one personality trait that differentiates the Turkish leaders from other world leaders, our group of Turkish leaders as a whole has a considerably higher score in SC in comparison to the score of 
the LTA norming group on this trait. Among themselves, the Turkish leaders we examined in this research show some stark differences, although some leaders are more similar to each other than others in terms of their personality traits and styles. Our LTA results suggested that Özal and Ecevit had an actively-independent leadership style, and Erbakan illustrated the style of an evangelical leader. In contrast, the leadership style of Gül was either incremental or opportunistic and that of Demirel was either evangelical or directive, depending on how open they were to incoming information. Similarly, our analysis put Erdoğan's leadership style in both expansionist and actively-independent categories, again based on whether or not he is open to information.

In addition, our in-depth analysis of 18 Turkish foreign policy cases suggest a high level of match between the leadership styles and how these leaders behaved during the policymaking process. In fact, we observed both Özal and Ecevit's actively-independent leadership styles in all of the case studies we examined during their tenures. Similarly, we were able to discern Demirel's directive and Erdoğan's expansionist styles in the relevant foreign policy cases. In two of the case studies we examined during the tenure of Gül, we found that he followed an incrementalist approach. We determined that he acted as an opportunistic leader in the third case. Finally, Erbakan's evangelical leadership style was clearly observable in two of the three case studies we analyzed.

Based on these findings, we conclude that LTA, with its rigorous and welltested profiling techniques is very successful in linking different leadership styles to actual foreign policy behavior. In fact, our study takes the study of leadership traits and styles a step further by using LTA and contributes to this burgeoning literature by comparing several different leaders, from a multi-method perspective, in a non-U.S. or Western European context. Despite the ongoing importance of LTA's predictive capability, however, we claim that the LTA-based research is in need of more nuance, especially when it comes to three areas.

First, it is important that scholars who conduct LTA-based research focus on detecting certain personality traits of younger leaders or leaders who are relatively newer in tackling issues in foreign affairs. Within this context, and secondly, it is important that LTA-based research continue to consider how time and experience impact a leader's style. For example, while the LTA scores for Erdoğan in the time frame we focused in this research suggest that he has low self-confidence, none of the cases we examined showed that this was in fact the case. Similarly, it was hard to show empirically his low scores on in-group bias and distrust towards others. Again, although the overall measurement and the way different traits were combined that resulted him being categorized as an 'expansionist' leader was on target, our case analyses revealed that his scores on some of the individual trait analyses were rather questionable. This is important especially when one 
considers the increasingly authoritarian style of Erdogan in recent years. In this regard, we strongly suggest that LTA-based research is complemented with in-depth case analysis because this kind of analysis provides an excellent way to study the impact of leaders' styles on foreign policy.

Third, the LTA-based research would benefit from an intentional focus on the question of how changes in institutional roles might impact the style of a leader. As we mentioned in the beginning, structuralists argue that leaders' actions and decisions are a product of their institutional role. In contrast, personality theorists do not see individuals as static across roles. For them, the personality-role (or agent-structure) relationship is conceptualized as interactionist. In other words, individuals do not simply wear and change roles as they would clothes; their personalities shape both the degree to which they mold themselves to roles, and the manner in which they play their role. Moreover, personality approaches would expect individuals, and some personality types more than others, to develop their interactions with their role (and the institutional environment in which their role resides) over time. In other words, individuals engage in 'role-learning. ${ }^{39}$ Taking an interactionist perspective, some scholars have argued that the permanence of a trait across situations (or roles) is itself a personality characteristic and varies across leaders. ${ }^{40}$ According to Dille and Young, however, 'such an argument would need to be supported by further inquiry into trait variability under more controlled circumstances. ${ }^{41}$ A recent study specifically examines changes in LTA traits across role positions. ${ }^{42}$ However, there is still much to be done in this area of LTA-based research.

In addition to these issues, it is also important to study further how similar or different leaders with same or similar leadership styles act under different types of structural constraints. For example, do leaders find it more difficult to challenge international constraints or domestic constraints? Are institutional limitations create more hurdles than cultural ones? Studies have shown that leaders with same leadership styles act similarly in different structural conditions. For example, in their assessment of the correlation between leadership styles of prime ministers and their behavior during the decision making process in Germany and Britain, Kaarbo and Hermann found that leaders in both countries showed both within- and across-country variation in leadership styles, with Germany predominantly having coalition governments and Britain single-party cabinets. ${ }^{43}$ Despite differences in structural settings, Germany's Konrad Adenauer and Britain's Margaret Thatcher both exhibited different type of leadership than Germany's Helmut Kohl and Britain's John Major. Both Adenauer and Thatcher took charge and dominated the political system in both countries, thus illustrating the style of an expansionist leader. On the other hand, Kohl gave importance to timing depending on the nature of the political system and exemplified the characteristics of a strategist. Britain's Major still showed a different type of leadership style. As a leader 
having an opportunistic leadership style, Major considered political context to be an important factor in his decision making calculations. In short, while Thatcher and Adenauer, working under different structural constraints in a single-party government and a coalition, respectively, created a political environment in which they could be assertive and directive, Major and Kohl preferred to work in a way that would make them be strategic and conciliatory.

Finally, LTA-based research needs to consider the question of how personalities might change depending on audience. One of her earlier studies, Hermann considered, along with topic and spontaneity, if personalities of Soviet Politburo members changed when they had different audiences. ${ }^{44}$ She found that task focus was the most sensitive to all three situational factors whereas scores for distrust of others and self-confidence were the least influenced traits. Hermann also concluded that Soviet leaders' ingroup bias scores changed noticeably depending on their audience. The question that has remained since then is what is to what extent leaders' personality traits scores would differ across domestic and international audiences, topics and time, especially in crisis situations. Scholars are just beginning to pay attention to this question, ${ }^{45}$ which paves the way for an interesting and productive line of exploration in the literature.

\section{Notes}

1. Quoted in Winter, "Personality," 108. See also Kesgin, "Tanus Ciller's Leadership Traits," 29.

2. See, among many, Kaarbo and Hermann, "Leadership Styles," and Schafer and Walker, Beliefs and Leadership.

3. Kaarbo and Hermann, "Leadership Styles," 245.

4. Heper and Sayari, Political Leaders, vii.

5. Dessler, "What is at Stake," 443.

6. Giddens, The Constitution of Society.

7. See, for example, Gilpin, War and Change; Keohane, "International Institutions"; Waltz, Theory of International Politics; Krasner, International Regimes; and Keohane and Nye, Power and Interdependence.

8. Guner and Koc, "Leverages and Constraints."

9. Kirisci and Kaptanoglu, "The Politics of Trade."

10. Tezcur and Grigorescu, "Activism."

11. See, for example, Wendt, Social Theory; Finnemore and Sikkink, "International Norm Dynamics"; and Bozdaglioglu, Turkish Foreign Policy.

12. See, for example, Katzenstein, The Culture; Berger, Cultures of Antimitiliarism; and Hopf, Social Construction.

13. Yanik, "Constructing Turkish "Exceptionalism."

14. Bilgin, "Only Strong."

15. See Owen, "How Liberalism."

16. See Russett, Grasping the Democratic Peace; Lektzian and Souva, "A Comparative Theory Test"; Debs and Goemans, "Regime Type"; and Valentino, Huth, and Croco, "Bear Any Burden." 
17. See Bueno de Mesquita et al., The Logic; Lai and Slater, "Institutions"; Lobell, Ripsman, and Taliaferro, Neoclassical Realism; and Dueck, "Neoclassical Realism."

18. See Hagan et al., "Foreign Policy"; Palmer, London, and Regan, "What's Stopping You"; Ozkececi-Taner, The Role of Ideas, and "The Role of Institutionalized Ideas"; and Kaarbo, Coalition Politics, and "Power and Influence."

19. Hermann and Hermann. "Who Makes Foreign Policy," and Hagan et al., "Foreign Policy."

20. Keller, "Constraint Respecters," 838.

21. Keller, "Constraint Respecters," 836-837, italics in original.

22. For arguments on the importance of personalities in Middle East foreign policy specifically, see Darwich and Kaarbo, "IR."

23. Walker, Role Theory, 13.

24. Dessler, "What is at Stake", 471

25. The timeframe we have for Recep Tayyip Erdogan's profile is between 2002 and 2013. This timeframe is important to understand the discussions then about the transitioning of Turkish political system from a parliamentary system to a presidential system.

26. Çuhadar et al., "Examining Leaders' Orientations."

27. See Hermann, "Assessing Leadership Style," "Explaining Foreign Policy Behavior," Handbook, "Leaders," and "Personality."

28. Walker, "Assessing Psychological Characteristics," and Schafer, "At-a-distance analysis."

29. Hermann, "Leaders," and "Personality"; Kesgin, "Uncharacteristic"; Kille and Scully, "Executive Heads"; Mastors, "Gerry Adams"; Preston, The President; Taysir and Preston, "The Personality"; van Esch and Swinkels, "How Europe's Political Leaders"; and Brummer, "Fiasco."

30. Hermann, "Assessing Leadership Style."

31. Walker, "Assessing Psychological Characteristics," and Schafer, "At-a-distance analysis."

32. Levine and Young, "Leadership Trait Analysis." ProfilerPlus is developed by Social Science Automation. The company is headed by Michael Young. Margaret Hermann was a co-founder in 1997. In ProfilerPlus, Young and colleagues converted hand-coding practices in leadership assessment to automated coding.

33. Hermann ("Assessing Leadership Style") provides a detailed description of how scores are calculated on each personality trait.

34. See Hermann, Handbook, and "Leaders," as well as Winter, "Measuring Personality."

35. Hermann, "Personality," and "Assessing Leadership Style."

36. Hermann, "Assessing Leadership Style," 193.

37. Preston, The President, 17. For a recent discussion and exploration of validity, see Dyson and Raleigh, "Public and Private Beliefs," and Kesgin "Turkey's Erdoğan."

38. Detailed analyses of these case studies are available upon request from the authors.

39. Harnisch, "Conceptualizing the Minefield"; Malici, Reagan and Gorbachev"; and Malici and Malici, "The Operational Codes.

40. Hermann, "Leaders' Foreign Policy Role Orientations," and Hermann and Hermann, "Who Makes." 
41. Dille and Young, "The Conceptual Complexity," 594.

42. Çuhadar et al., "Personality or Role."

43. Kaarbo and Hermann, "Leadership Styles."

44. Hermann, "Assessing the Personalities."

45. See, for example, Kesgin, "Turkey's Erdoğan.”

\section{Acknowledgements}

We also thank Social Science Automation for making ProfilerPlus available. An earlier version of this paper was presented at the International Studies Association Convention in 2015; we would like to thank our discussant Stephen B. Dyson for his helpful comments. Finally, we extend our thanks to two anonymous reviewers and the journal's editorial team for their constructive feedback.

\section{Disclosure statement}

No potential conflict of interest was reported by the author(s).

\section{Funding}

The authors gratefully acknowledge that this research was supported by a TUBITAK Evrena grant (110K112).

\section{Note on contributors}

Esra Cuhadar is an Associate Professor at the Department of Political Science and Public Administration at Bilkent University in Turkey and a Senior Fellow at the Inclusive Peace and Transition Initiative at the Graduate Institue, Geneva. Most recently, she was a Jennings Randolph Senior Fellow at the United States Institute of Peace (USIP) in 2018. Dr. Cuhadar's research interests include political leadership, inclusive peace processes, mediation, track two diplomacy and role of civil society in peacebuilding, and negotiation pedagogy among others. Her research has been published in top academic journals such as Political Psychology, Journal of Peace Research, Computers in Human Behavior, Negotiation and Conflict Management, Mediterranean Politics, International Politics, and Turkish Studies. Dr. Cuhadar received one of the Young Scientist awards given by the Science Academy in Turkey in addition to research grants from USIP, Sabanci University, TUBITAK, and German Marshall Fund.

Juliet Kaarbo is Professor of International Relations with a Chair in Foreign Policy at the University of Edinburgh. She is founding co-director of Edinburgh's Centre for Security Research. Her research focuses on leader personality and decision making, group dynamics, foreign policy analysis and theory, parliaments and parties, and national roles and has appeared in journals such as International Studies Quarterly, European Journal of International Relations, International Studies Review, Political Psychology, West European Politics, Cooperation and Conflict, and Foreign Policy Analysis. In 2012, Professor Kaarbo published Coalition Politics and Cabinet Decision Making; and, in 2016 she co-edited Domestic Role Contestation, Foreign Policy, and 
International Relations. She was awarded the 2018 Distinguished Scholar of Foreign Policy Analysis by the International Studies Association.

Barış Kesgin is Assistant Professor of Political Science and Associate Coordinator for the International and Global Studies Program at Elon University. His research focuses on the role of leaders' personalities on Israeli and Turkish foreign policy. His publications have appeared in Cooperation and Conflict, International Area Studies Review, International Studies Perspectives, Journal of International Relations and Development, and Political Psychology.

Binnur Ozkececi-Taner is Professor of Political Science in Hamline University's College of Liberal Arts. She has published numerous articles and book chapters on foreign policy analysis and Turkish foreign policy. Her publications have appeared in Foreign Policy Analysis, International Studies Review, Mediterranean Politics, Political Psychology, and Turkish Studies. She holds a BA in International Relations from the Middle East Technical University (Ankara), an MA in Peace Studies from the University of Notre Dame's Kroc Institute, and a PhD in Political Science from Syracuse University.

\section{ORCID}

Barış Kesgin (D) http://orcid.org/0000-0002-6108-8240

Binnur Özkeçeci-Taner (D) http://orcid.org/0000-0001-8100-6559

\section{Bibliography}

Berger, Thomas. Cultures of Antimitiliarism: National Security in Germany and Japan. Washington, DC: Johns Hopkins University Press, 1998.

Bilgin, Pinar. “'Only Strong States Can Survive in Turkey's Geography': The Uses of 'Geopolitical Truths' in Turkey.” Political Geography 26 (2007): 740-756.

Bozdaglioglu, Yucel. Turkish Foreign Policy and Turkish Identity: A Constructivist Approach. New York: Routledge, 2003.

Brummer, Klaus. “'Fiasco Prime Ministers': Leaders' Beliefs and Personality Traits as Possible Causes for Policy Fiascos." Journal of European Public Policy 2, no. 5 (2016): 702-717.

Bueno de Mesquita, Bruce, Alastair Smith, Randolph Siverson, and James Morrow. The Logic of Political Survival. Cambridge, MA: MIT Press, 2003.

Carlsnaes, Walter. "The Agency-Structure Problem in Foreign Policy Analysis." International Studies Quarterly 36 (1992): 245-270.

Chiozza, Giacomo, and Hein Goemans. Leaders and International Conflict. New York: Cambridge University Press, 2011.

Crichlow, Scott. "Idealism or Pragmatism? An Operational Code Analysis of Yitzhak Rabin and Shimon Peres." Political Psychology 19, no. 4 (1998): 683-706.

Çuhadar, Esra, Juliet Kaarbo, Barış Kesgin, and Binnur Özkeçeci-Taner. "Examining Leaders' Orientations to Structural Constraints: Turkey's 1991 and 2003 Iraqi War Decisions." Journal of International Relations and Development 20, no. 1 (2017): 29-54.

Çuhadar, Esra, Juliet Kaarbo, Barış Kesgin, and Binnur Özkeçeci-Taner. "Personality or Role? Comparisons of Turkish Leaders Across Different Institutional Positions." Political Psychology 38, no. 1 (2017): 39-54. 
Darwich, May, and Juliet Kaarbo. "IR in the Middle East: A Foreign Policy Analysis Perspective on Domestic and Decision Making Factors in Theoretical Approaches." International Relations (2019). doi:10.1177/0047117819870238.

Debs, Alexandre, and H. E. Goemans. "Regime Type, the Fate of Leaders, and War." American Political Science Review 104, no. 3 (2010): 430-445.

Dessler, David. "What is at Stake in the Agent-Structure Debate?" International Organization 43 (1989): 441-473.

Dille, Brian, and Michael Young. "The Conceptual Complexity of Presidents Carter and Clinton: An Automated Content Analysis of Temporal Stability and Source Bias.” Political Psychology 21 (2000): 587-595.

Dueck, Colin. "Neoclassical Realism and the National Interests: Presidents, Domestic Politics, and Major Military Interventions." In Neoclassical Realism, the State, and Foreign Policy, edited by Steven Lobell, N. M. Ripsman, and J. W. Taliaferro, 139169. Cambridge: Cambridge University Press, 2009.

Dyson, Stephen. "Personality and Foreign Policy: Tony Blair's Iraq Decisions." Foreign Policy Analysis 3 (2006): 289-306.

Dyson, Stephen, and Alexandra L. Raleigh. "Public and Private Beliefs of Political Leaders: Saddam Hussein in Front of a Crowd and Behind Closed Doors." Research and Politics April-June (2014): 1-7.

Feng, Huiyun. "Crisis Deferred: An Operational Code Analysis of Chinese Leaders Across the Strait." In Beliefs and Leadership in World Politics: Methods and Applications of Operational Code Analysis, edited by Mark Schafer and Stephen Walker, 151-170. New York: Palgrave Macmillan, 2006.

Finnemore, Martha, and Kathryn Sikkink. "International Norm Dynamics and Political Change.” International Organization 52 (1998): 887-918.

Giddens, Anthony. The Constitution of Society. Outline of the Theory of Structuration. Cambridge: Polity, 1984.

Gilpin, Robert. War and Change in World Politics. Cambridge: Cambridge University Press, 1983.

Goldgeier, James. "Psychology and Security.” International Security 6, no. 4 (1997): 137-166.

Guner, Serdar, and Dilan Koc. "Leverages and Constraints for Turkish Foreign Policy in Syrian War: A Structural Balance Approach.” Uluslararasi Iliskiler Dergisi 15 (2018): 89-103.

Hagan, Joe D., Philip P. Everts, Haruhiro Fukui, and John D. Stempel. "Foreign Policy by Coalition: Deadlock, Compromise, Anarchy." International Studies Review 3, no. 2 (2001): 169-216.

Harnisch, Sebastian. "Conceptualizing the Minefield: Role Theory and Foreign Policy Learning." Foreign Policy Analysis 9 (2012): 47-69.

Heper, Metin, and Sabri Sayari, eds. Political Leaders and Democracy in Turkey. Lanham MD: Lexington Books, 2002.

Hermann, Margaret. "Assessing the Personalities of Soviet Politburo Members." Personality and Social Psychology Bulletin 6, no. 3 (1980): 332-352.

Hermann, Margaret. "Explaining Foreign Policy Behavior Using the Personal Characteristics of Political Leaders." International Studies Quarterly 24, no. 1 (1980): 7-46.

Hermann, Margaret. Handbook for Assessing Personal Characteristics and Foreign Policy Orientations of Political Leaders. Columbus, OH: Mershon Center, 1983.

Hermann, Margaret. "Personality and Foreign Policy Decision-Making: A Study of 53 Heads of Government." In Foreign Policy Decisionmaking: Perceptions, Cognition, 
and Artificial Intelligence, edited by Donald A. Sylvan, and Steve Chan, 53-80. New York: Praeger, 1984.

Hermann, Margaret. "Leaders' Foreign Policy Role Orientations and the Quality of Foreign Policy Decisions." In Role Theory and Foreign Policy Analysis, edited by Stephen Walker, 123-140. Durham NC: Duke University Press, 1987.

Hermann, Margaret. "Assessing Leadership Style: A Traits Analysis." In The Psychological Assessment of Political Leaders: With Profiles of Saddam Hussein and Bill Clinton, edited by Jerrold Post, 178-215. Ann Arbor: University of Michigan Press, 2003.

Hermann, Margaret, and Charles Hermann. "Who Makes Foreign Policy Decisions and How? An Empirical Inquiry.” International Studies Quarterly 33 (1989): 361-387.

Hopf, Ted. Social Construction of International Politics. Ithaca: Cornell University Press, 2002.

Kaarbo, Juliet. "Power and Influence in Foreign Policy Decision Making: The Role of Junior Coalition Partners in German and Israeli Foreign Policy." International Studies Quarterly 40 (1996): 501-530.

Kaarbo, Juliet. Coalition Politics and Cabinet Decision Making: A Comparative Analysis of Foreign Policy Choices. Ann Arbor: University of Michigan Press, 2012.

Kaarbo, Juliet, and Margaret G. Hermann. "Leadership Styles of Prime Ministers: How Individual Differences Affect the Policymaking Process." Leadership Quarterly 9 (1998): 243-263.

Katzenstein, Peter. The Culture of National Security. New York: Columbia University Press, 1996.

Keller, Jonathan. "Constraint Respecters, Constraint Challengers, and Crisis Decision Making in Democracies: A Case Study Analysis of Kennedy vs. Reagan.” Political Psychology 26, no. 6 (2005): 835-867.

Keohane, Robert. “International Institutions: Two Approaches.” International Studies Quarterly 32 (1988): 379-396.

Keohane, Robert, and Joseph Nye. Power and Interdependence: World Politics in Transition. Cambridge, MA: Harvard University Press, 1977.

Kesgin, Barış. “Tansu Ciller's Leadership Traits and Foreign Policy.” Perceptions: A Journal of International Affairs 17, no. 3 (2012): 29-50.

Kesgin, Barıș. "Leadership Traits of Turkey's Islamist and Secular Prime Ministers." Turkish Studies 14, no. 1 (2013): 136-157.

Kesgin, Barış. "Uncharacteristic Foreign Policy Behavior: Sharon's Decision to Withdraw from Gaza." International Area Studies Review 22, no. 1 (2019): 76-92.

Kesgin, Barış. “Turkey’s Erdoğan: Leadership Style and Foreign Policy Audiences.” Turkish Studies 21, no. 1 (2020): 56-82.

Kille, Kent J., and Roger M. Scully. "Executive Heads and the Role of Intergovernmental Organizations: Expansionist Leadership in the United Nations and the European Union.” Political Psychology 24, no. 1 (2003): 175-198.

Kirisci, Kemal, and Neslihan Kaptanoglu. "The Politics of Trade and Turkish Foreign Policy.” Middle Eastern Studies 47, no. 5 (2011): 705-724.

Krasner, Stephen, ed. International Regimes. Ithaca, NY: Cornell University Press, 1983.

Lai, Brian, and Dan Slater. "Institutions of the Offensive: Domestic Sources of Dispute Initiation in Authoritarian Regimes, 1950-1992." American Journal of Political Science 50, no. 1 (2006): 113-126.

Lektzian, David, and Mark Souva. "A Comparative Theory Test of Democratic Peace Arguments." Journal of Peace Research 46, no. 1 (2009): 17-37. 
Levine, Nick, and Michael Young. "Leadership Trait Analysis and Threat Assessment with Profiler Plus." Proceedings of ILC on 8th international Lisp Conference, Association for Computing Machinery, Montreal, Canada, 2014.

Lobell, Steve, Norrin Ripsman, Jeffrey W. Taliaferro, eds. Neoclassical Realism, The State, and Foreign Policy. Cambridge: Cambridge University Press, 2009.

Malici, Akan. "Reagan and Gorbachev: Altercasting at the End of the Cold War." In Beliefs and Leadership in World Politics: Methods and Applications of Operational Code Analysis, edited by Mark Schafer and Stephen Walker, 127-149. New York: Palgrave Macmillan, 2006.

Malici, Akan, and Johnna Malici. "The Operational Codes of Fidel Castro and Kim-Il Sung: The Last Cold Warriors?” Political Psychology 26, no. 3 (2005): 387-412.

Mastors, Elena. "Gerry Adams and the Northern Ireland Peace Process." Political Psychology 21 (2000): 839-846.

Owen, John. "How Liberalism Produces Democratic Peace." International Security 19 (1994): 87-125.

Özkeçeci-Taner, Binnur. "The Role of Institutionalized Ideas in Coalition Foreign Policymaking: The Case of Turkey, 1991-2002." Foreign Policy Analysis 1, no. 3 (2005): 249-278.

Özkeçeci-Taner, Binnur. The Role of Ideas in Coalition Government Foreign Policymaking: The Case of Turkey Between 1991 and 2002. Geneva IL: Republic of Letters Publishers, 2009.

Palmer, Glenn, Tamar London, and Patrick Regan. "What's Stopping You?: The Sources of Political Constraints on International Conflict Behavior in Parliamentary Democracies.” International Interactions 30 (2004): 1-24.

Preston, Thomas. The President and his Inner Circle: Leadership Style and the Advisory Process in Foreign Affairs. New York: Columbia University Press, 2001.

Renshon, Jonathan. "Stability and Change in Belief Systems: The Operational Code of George W. Bush From Governor to Second-Term President." Journal of Conflict Resolution 52 (2008): 820-849.

Russett, Bruce. Grasping the Democratic Peace: Principles for a Post-Cold War. Princeton: Princeton University Press, 1993.

Schafer, Mark. "At-A-Distance Analysis." In The Oxford Handbook of Political Leadership, edited by R. A. W. Rhodes, and Paul 't Hart, 296-313. Oxford: Oxford University Press, 2014.

Schafer, Mark, and Stephen Walker, eds. Beliefs and Leadership in World Politics: Methods and Applications of Operational Code Analysis. New York: Palgrave Macmillan, 2006.

Strangio, P., Paul 't Hart, and J. Walter, eds. Understanding Prime-Ministerial Performance: Comparative Perspectives. Oxford: Oxford University Press, 2013.

Taysir, Tanyel, and Thomas Preston. "The Personality and Leadership Style of President Khatami: Implications for the Future of Iranian Political Reform." In Profiling Political Leaders: A Cross-Cultural Studies of Personality and Behavior, edited by Ofer Feldman, and Linda O. Valenty, 57-77. Westport, CT: Praeger, 2001.

Tezcur, Gunes, and Alexander Grigorescu. "Activism in Turkish Foreign Policy: Balancing European and Regional Interests." International Studies Perspectives 15, no. 3 (2014): 257-276.

Valentino, Benjamin, Paul K. Huth, and Sarah E Croco. "Bear Any Burden? How Democracies Minimize the Costs of War." The Journal of Politics 72, no. 2 (2010): 538-544. 
Van Esch, Femke, and Marij Swinkels. "How Europe's Political Leaders Made Sense of the Euro Crisis: The Influence of Pressure and Personality." West European Politics 38, no. 6 (2015): 1203-1225.

Walker, Stephen. “Assessing Psychological Characteristics At-a-Distance: Symposium Lessons and Future Research Directions.” Political Psychology 21 (2000): 597-601.

Walker, Stephen. Role Theory and the Cognitive Architecture of British Appeasement Decisions. New York: Routledge, 2013.

Waltz, Kenneth. Theory of International Politics. Reading, MA: Addison-Wesley, 1979.

Wendt, Alexander. Social Theory of International Politics. Cambridge: Cambridge University Press, 1999.

Winter, David. "Measuring Personality at a Distance: Development of an Integrated System for Scoring Motives in Running Text." In Perspectives in Personality, Vol. 3, Part B: Approaches to Understanding Lives, edited by A. J. Stewart, J. M. Healy Jr., and D. J. Ozer, 59-89. London: Jessica Kingsley Publishers, 1991.

Winter, David. "Personality and Political Behavior." In Oxford Handbook of Political Psychology, edited by David O. Sears, Leonie Huddy, Robert Jervis, 110-145. London: Oxford University Press, 2003.

Yanik, Lerna. "Constructing Turkish 'Exceptionalism': Discourses of Liminality and Hybridity in post-Cold War Turkish Foreign Policy." Political Geography 30, no. 2 (2011): 80-89.

Young, Michael D., and Victoria Shafer. "Correlations among Leadership Trait Analysis and Operational Code Indicators." Paper presented at the 46th Annual Convention of the international Studies Association, Honolulu, Hawaii, 2005. 